\title{
The Present State of Unpopular Music ${ }^{1}$ John Beckwith
}

(The text is followed by an abstract in French.)

In 1981, at the invitation of a journal in Australia, I produced a short essay called "Composing in the Eighties" (reprinted in Beckwith 1997b, 204-212). Fifteen years later, at the 1997 CUMS meeting at Memorial University, I delivered what might be called an up-date, under the title "Accessibility, elitism, oblivion: options for the composer" (Beckwith 1997a). Recycling this piece at a couple of other universities, I headed it more simply "Composing in the Nineties." Now, a decade further on, I've put together yet more comments, for which a suitable name might be "De-composing in the Aughties."

The 1981 paper reviewed the designations applied to the sort of music I and my colleagues produce. Already then, but much more in the twenty-five years since, the musical repertoire was split into myriad distinct genres, among which "contemporary classical” appeared as a faint trace on the map. The nomenclature remains an issue, and the splitting has continued; on that, more comment shortly. The essay also dealt with the teaching of composition, and with particular difficulties of the contemporary composer's task such as the omnipresence of ambient sounds like Muzak that weaken listeners' alertness. In 1997, my focus was more on the compositional product, on music itself - especially our increased attention to formerly-little-known works from the Eastern European bloc, and the pressure on younger composers to make their pieces "accessible" (smooth easy ramps rather than challenging staircases). In offering an analysis of one of the huge successes of the 90s, I noted that in the mid-90s the Third Symphony of Henryk Gorecki had appeared on more Canadian orchestral programs than any symphonic work by a Canadian composer. Its predominance has waned, but the idiom of simplicity and spirituality continues strong, and this will be a topic for new observations in a moment.

Music is always changing. In the early 1970 s I was advising students to keep their definition of music open. In the 60s, bewildered parents had confronted the new pop music their children were enthusing over with the cry, "Whatever it is, it certainly isn't music." That same cry has resounded at crucial moments throughout musical history. But, like it or not, musical styles are always changing. From personal experience, as an example close to home, I would pinpoint a significant historical change in musical values from a particular event-a special members' meeting of SOCAN, held in Toronto on 9 January 1992.

\footnotetext{
${ }^{1}$ This paper originated as a talk given at the joint meeting of the Canadian University Music Society and the Canadian Association of Music Libraries, at the Université de Montréal, on 12 May 2007.
} 
SOCAN $^{2}$ was a new organization, created scarcely two years earlier through the merger of the two Canadian performing-rights societies, CAPAC and ProCan. ${ }^{3}$ Neither of the rival merging bodies had ever had an elected board, so the purpose of this meeting was to approve an election procedure for SOCAN. The plan, which after much debate received overwhelming acceptance, allowed for an eighteen-member board, nine of whom were to be "writers" (that is, composers or lyricists) and nine "publishers" (meaning producers not so much of sheet music as of recordings). Moreover, the writers were to be distinguished as either "classical" or "popular," and both categories would be guaranteed representation. The meeting decided on the term "serious" for the "classical" writers, leaving the "popular" writers with the negative characterization "non-serious." Potential board members might be both serious and non-serious, but for election would be obliged to declare themselves one or the other. Of the nine writer members on the board, at least two but not more than four would be serious, and at least five non-serious. Of the nine publisher members, at least one would be serious; no maximum was suggested here, implying that all nine might be serious, but everyone familiar with the scene realized serious publishing and recording is such minor-league territory in Canada that that could not

${ }^{2}$ Society of Composers, Authors, and Music Publishers of Canada / Société des auteurs, compositeurs et éditeurs de musique.

${ }^{3}$ Composers, Authors, and Publishers Association of Canada / Association des compositeurs, auteurs et éditeurs du Canada; Performing Rights Organization of Canada / Société de droits d'exécution du Canada. conceivably happen. Further provisions assured regional and linguistic balance in the election process.

Many serious composers attended the meeting. Indeed serious composers had been key players in founding and operating both parent societies. The new structure guaranteed they would never have a majority voice in SOCAN. How did this plan pass so overwhelmingly? The explanation is that votes were weighted according to each member's earnings within the royalties collected by SOCAN. The vote of a composer whose twenty-minute concerto had just been played by a couple of Canadian orchestras would merit a multiplication factor of four; a songwriter somewhere high on the charts, a multiplication factor of four hundred. Democracy in action!

Within a year the new SOCAN board abolished the established policies for distribution of the performance royalties it collects. Former practice favored "serious" creativity, recognizing that writing a successful popular song demanded less expenditure of energy and skill but had a vastly greater chance of commercial compensation than composing a successful string quartet. Where the pop song may be repeated daily for weeks if not months on both local and network radio, the most the quartet can expect is to be played before a live audience, perhaps recorded for broadcast, and perhaps repeated a few times. Recognition took the form of a sliding scale for the various categories. But now, in 1992, there was to be no more sliding scale: popular songs and symphonic compositions were to be evaluated equally, the sole criterion being length (that is, timing). In the experience of one moderatelyactive composer, royalty earnings in the 1990s 
gradually declined to one-twelfth of their previous level. His "non-serious" colleagues considered this fair treatment: in their imagination, he received commissions and arts council grants and they didn’t.

The episode illustrates what happens when you apply business thinking to music. Indeed, when a large group of composers met with the SOCAN board in Montreal later that same year, it was Jean Papineau-Couture who reminded everyone that SOCAN was a nonprofit agency - a society, not a company. But throughout the world, business procedure and business success has become more and more the watchword. The business approach of SOCAN is paralleled in the equivalent organizations in most countries of Western Europe and North America, although the older distribution patterns still exist elsewhere here and there, notably in Scandinavia and Japan.

I hope this doesn't sound like sour grapes. I don't mean it that way. But the abrupt change in SOCAN, I believe, symbolizes a marked shift in society's view of music. Another sign could be the gradual shrinkage of attention to serious new music in the media. In the New Yorker's first twenty issues of 1992 there were eleven full-length reviews by the then music critic, Andrew Porter. In the first twenty issues of 2002, ten years later, Porter's successor Alex Ross published six reviews. Where Porter touched only classical and contemporary-classical events, Ross's purview extends to a wide gamut of current popular forms. Closer to home, a similarly wide gamut is now covered by the main critic of the Globe and Mail, Robert Everett-Green - something that could never have been imagined in the tenure of the previous Globe music critic: John Kraglund, who retired in the 1980s, wrote exclusively about classical events. Or how about this symbol? Going into a store with the sign "Music" thirty or forty years ago, you would expect to see sheet music for sale. Under the same sign today you're more likely to find pop CDs and a selection of electro-acoustic instruments.

As a teacher I have always urged students to actively listen to music rather than just passively absorbing it. Music has structure and meaning alongside its swaying or propulsive motion, its textures and timbres, and its catchy melody contours, I argued; so, pay attention. But in the past decade, more and more, technology has transformed how music reaches us. Rather than in immediate performance ("live," as we say) in a concert hall, we're more likely to hear it on the radio, on a disc player, or on a mobile phone or personal computer. Those would still be potential scenarios for active attention. But think, by contrast, of the fragmented snatches of music you hear when on-hold in a phone call, or above the clatter of dishes in a restaurant or go-carts in a grocery or of conversation in a hotel lobby or air terminal. The clatter and the musical echoes are interrupted every few minutes with recorded announcements that your plane is about to take off, an employee is wanted at the customer service desk, the store has a special on frozen peas, or, God help us, "your call is important." Paying attention to the music becomes harder. A newspaper description of a late-model iPod says one of the handy features is that the music will automatically turn off when a phone call comes in. Great: you're following Anton Kuerti in that exciting build-up to the recapitulation in the first movement of the Waldstein Sonata or Charles Dutoit as he and his players reach that exalted final tutti of $\mathrm{La} \mathrm{Mer} \mathrm{-} \mathrm{and} \mathrm{ding!} \mathrm{some}$ clunkhead is on the line about a magazine 
subscription. Radio seems to be now designed with such interruptions built in - you know, those musical snippets with voice-over during the Met opera broadcasts. You've just heard a live rendition of the first act of $\mathrm{La}$ traviata, and while you're contemplating how it will develop in Act 2 you're exposed to "Met highlights" consisting of ten bars of the triumphal march from Aida and the last page of the "Liebestod" from Tristan, both played at the same volume as the opera you've tuned in to hear. Or else, a phrase or two from the overture to Figaro runs behind an announcement that it will be the featured opera next week. What does this do to your sense of music as a continuity of images and ideas?

My examples are from the European classics, but newly composed music receives the same casual handling by both producers and consumers. And of course most filler music is neither Mozart nor Elliott Carter, but from some popular genre or other. Given that many, if not most, popular genres lean a lot on raw emotionality, their creators are as entitled as Mozart or Carter to resent having their outbursts treated so casually.

With the growth of sophisticated technology for sound transmission, the pop genres have proliferated amazingly. The other day I clipped from a newspaper an advertisement for satellite radio: it consisted of a full page listing all the types of music subscribers could enjoy on its various channels. What a range! - ragtime; jazz, cool jazz, smooth jazz, big band, swing; pop, pop lite, top twenty, Latin pop; contemporary; easy listening, new age; blues, rhythm and blues, country, bluegrass, folk; rap, hip-hop; soul, rock, punk, heavy metal; reggae, ska; indie, alternative;
gospel,Christian, world; chill (?); dance, trance, disco. ${ }^{4}$ It goes on even further.

You notice "contemporary” is included. The term doesn't refer to the serious sector. It used to, but it doesn't any more. When CBC Radio Two told us lately there would be greater emphasis on contemporary music in their new schedule, they meant they would be playing more middle-of-the-road pop; they didn't mean they would be playing more music by Harry Somers. Whenever Harry was asked what kind of music he composed, his wry answer was "unpopular music." But if we must consider music an "industry" and a "market," perhaps Harry's corner of it is no smaller than the share accorded to swing or trance or ska. If music ever addressed one unified audience, it certainly doesn't in the early twenty-first century. What we have in fact is an unprecedented array of many small markets or audiences.

Well, if not "unpopular," what do we call new composed music? In one of my previous surveys, I noticed that by 1990 everyone seemed to have settled on the term "classical" as the opposite of "popular," leaving Somers with "contemporary classical" for his little niche. We have also had "modern" as the opposite of "classical," but modernism now has a bad odor. In the 1970s, the musicologist H. Wiley Hitchcock promoted "cultivated," whose opposite was "vernacular" (Hitchcock 1969, [x]). That had a certain North American relevance. Elaine Keillor, in her 2006 book Music in Canada, offers "refined music" and "commercial music" as new variants (Keillor 2006, 363, note 11). I'm not sure many composers will like being called

\footnotetext{
${ }^{4}$ Globe and Mail, 27 March 2007, A5.
} 
"refined": doesn't it suggest crooking your little finger while holding your teacup? It's uncomfortably close to "elite," and for some time we've tried to avoid the suggestion that we're exclusive or a bunch of snobs. SOCAN, I'm happy to say, has abandoned "serious" and "non-serious": the 2007 ballot calls the two groups of nominees "concert composers" and "popular composers." In the society's house organ, Words and music, they're referred to as "composers" and "songwriters," which, in the context, makes good sense. "Concert music" remains a questionable designation, though, given that such works are performed in theatres, churches, and schools just as regularly as in concert halls, and probably most often in mechanical outlets such as those cited earlier. We'll probably never solve the problem of what to call this music.

What is it like? And how has it changed in the past, say, fifteen years? I said modernism has come to have a bad odor. This is probably because the critical cliché nowadays is that modernism in music is dead. In another talk, three years ago, I tried to recount the myth:

Around the First World War [I told my audience], music developed a sickness called Modernism...; the composers...(depraved characters like Stravinsky, Berg, Schoenberg, Bartok, Varèse) set out...to deliberately assault their hearers with unpleasant and complex mixtures of sound, garbled rhythms, distorted melodies, weird impossible-tofollow forms. After the Second World War..., music headed into even further extremes - works composed to strict scientific and mathematical formulas, or, at the other end of the spectrum, works composed by throwing dice or by the equivalent of pressing a lot of electric buzzers. A couple of decades later, having lost their audiences completely, composers acknowledged the error of their ways and discovered something called Accessibility: they began once again writing hummable tunes and fitting them to familiar chord patterns...

That outline [I continued] is a lot of nonsense. The highlights of the modernist repertoire, far from being dead, continue to be performed and enjoyed... (Beckwith 2005).

In his six-volume Oxford history of Western music, Richard Taruskin writes of the classical repertoire (the "literate tradition," as he calls it), from medieval notated chant through to the late twentieth century: "if its beginnings are known and explicable,... its dominance....[is] now in irreversible process of decline" (Taruskin 2005, introduction to v. 1). He locates the death rattle of the classical canon in the meditative and minimalist works of Tavener and Pärt, Western music in his view thus ending where it started, in Christian sacred song: "that sort of work," he says, "seems to be the most marketable and profitable music the literate tradition can boast at a time when...its end is foreseeable" (Taruskin 2005, v.5, 525). (Note the use of business language - "marketable and 
profitable.”) For Joseph Horowitz, author of Classical Music in America: a history of its rise and fall, the key figures on the U.S. musical landscape are not the composers but the performers (Horowitz 2005, xiv). Horowitz's account of the "fall" touches on relevant happenings in later-twentieth-century pop music. The pop music of the 1960s (to judge from consumer statistics) was among the most genuinely popular of any known music. Indeed, as Taruskin observes, it "became a transforming force affecting all other musics” (Taruskin 2005, v.5, 311). Roll over, Beethoven. In both these authors we may mark a growing tendency in U.S. music criticism and scholarship: rather than kowtow as colonials to an imported culture from imperial Europe, the new imperials regard the European mainstream - Bach, Beethoven, and company - as a dead issue, and erect their own cult figures (Copland, Gershwin, Ellington, Bernstein), their own mainstream of pluralist, egalitarian, and unassailably popular musical style.

In my 1997 paper, I prefaced my analysis of Gorecki with a general description of the "meditative-minimalist" mode. The music, I found, is "slow, steady, sustained; uniform in tone-color; built in repetitive simple patterns; 'spiritual' and/or melancholic in mood; low in intervallic profile; dynamically curving in a long steady crescendo which either ends high or sequences into an long decrescendo." If this prototype resembled a march, I suggested, it would be a march "not of soldiers on parade but of mourners in an extremely slow-moving and extremely sad funeral procession" (Beckwith 1997a). Messiaen might spring to mind as a "spiritual" forerunner. But his voluptuous textures and complex rhythmic processes bear little relation to this late- twentieth-century idiom with its unrelieved austerity.

Last month in Toronto I heard a live performance of Pärt's Passio, a setting in Latin of the passion of Christ as related in the Gospel of St John. My previous judgment of Pärt's music, I realized, had been based on too little first-hand knowledge. He has become the darling of the choral community; there is even an all-Pärt CD by a leading Canadian choir. I figured I should attend, and try to keep an open mind. The Passio calls for a large choir, an eight-voice solo ensemble, and two vocal soloists, supported by a selective instrumental team of oboe, bassoon, violin, and cello. In addition, an organ accompanies the words of Jesus. The piece lasts something over two hours. The text is set in uniform syllabic style with no change of rhythm pattern or tempo. The passages of text are broken with measured silences or very brief instrumental phrases. Variety of texture consists of alternating tutti, small-ensemble, and solo sections. The mood is uniform; there is no tone-painting. The individual lines confine themselves to the notes of the naturalminor scale of A, with an occasional G-sharp. At the very end everyone hollers a loud Dmajor chord on the word "Amen." I couldn't fault the performance; but, as for the work itself, I couldn't find it uplifting or moving; its slow-stepping deliberateness was for me a huge bore; I found myself wondering how much time and thought it had really cost the composer - wondering nastily if there was an element of hoax in this music's widelypublicized presence in the contemporary repertoire.

The inheritors of the classical tradition and of the tradition of twentieth-century modernism aren't all either adherents of the Tavener/Pärt 
school or obedient imitators of U.S. pop. Musical styles and trends of many kinds have co-existed in my lifetime, and continue to coexist, as I see it, today. An unswerving modernist, Elliott Carter, is productive and indeed swamped by commissions in his midnineties. When asked in Toronto last year whether he thought his music was "accessible," he cannily replied that it was obviously accessible to musicians. Call him elitist if you like; still, his work has both vigor and distinction. Look around: active figures such as Bolcom in America and Adès in Britain attract wide public attention, as do conservative orchestral specialists like Hétu and Kulesha here in Canada. So, some of the counter-currents in today's "serious" repertoire are complicated and surprisingly vital, which may make us question whether we actually are in a period of moribundity. The "wide public attention" I refer to, even if it's still only a faint trace on the overall musical map, is numerically larger than any audience Frédéric Chopin ever addressed.

I like to use the concept of a repertoire. But with our increasing pop-industry, businessmarket mentality, it seems we no longer preserve our best musical achievements. As Bruce Mather put it recently:

Of the entire production of the last sixty years, what has endured? Precious little!... We are fed a diet of first performances, and works written in the last two years an unbalanced programming. ${ }^{5}$

${ }^{5}$ Bruce Mather, letter to John Beckwith, 6 April 2007.
The business bias of the news media results in stories about the prize winners of novel contests or auction sales of paintings. Money prizes are thought to be of greater public interest than works of art. There is only one national money prize for composing in Canada, a modest one at that, and in order to be considered the composer has to make an application. ${ }^{6}$ In the thirty years since the inauguration of the Prix Léger, how many of the prize works have been recorded on CD? how many have been revived in live performance? Mather's point is well taken. The repertoire exists as an object of study but not as music we regularly hear.

Like most composers, Christos Hatzis would probably rather write music than write about music. But he has taken the time to produce two substantial essays and publish them on his website (Hatzis 2004, Hatzis 2006). ${ }^{7}$ Together they constitute both a manifesto for his own approach to composition and an attack on every other approach of the past hundred years. They are argued with impressive seriousness and deserve rebuttal.

For Hatzis, new music possesses "true art and creativity" when, beyond "technical mastery" it shows a "deeper connection with a transpersonal creative source.” Belonging to the Greek Orthodox faith, he however does not view spirituality as the exclusive property of one sect or religion. As contrasted to the "mind...conditioned by scientific language games," he favors the "mind that delights in [religious] experience.”

\footnotetext{
${ }^{6}$ The annual Prix Jules-Léger carries a cash prize of $\$ 7,500$.

${ }^{7}$ Unless otherwise noted, all quotations by this author are from these two essays.
} 
He sums up the aesthetic views of his colleagues as "language games," and questions the sincerity of their convictions. "We are most interested in convincing others," he writes, "when we are advocating something about which we are not entirely convinced ourselves” - surely a debatable psychological insight.

He refrains from naming his targets. Castigating avant-gardists of the period 1910 through 1950 as "pseudo-scientific" and as responsible for the "imperialistic tendencies of modernism," he leaves his readers to guess which modernists he means: Ravel? Bartok? Berg? Stravinsky? Varèse? Postmodernists he dismisses as "nihilistic." Does he mean Feldman? or perhaps (in Canada) Rea or Komorous? He doesn't say. In the later century, he cites a school of "hard-core elitists" as clashing with something called the "new populism." Who are the "elitists"? You are left to cast the drama yourself; likely figures might be Birtwistle or Carter or Boulez, but again Hatzis doesn't specify. As for the "new populism," he says: "divorced from its spiritual undercurrent [it] is...a musical perversion [...and] may not be that different from commercial products by the music industry that are presently contaminating our acoustic ecology.” I'm imagining Philip Glass and Gavin Bryars as the implied villains this time, though neither is cited. Perhaps predictably, the only contemporaries Hatzis does mention, and in this case with approval, are John Tavener and Arvo Pärt - composers whose musical vocabulary derives, like that of Hatzis, from religious chant traditions, Greek Orthodox and Roman Catholic respectively.
His own most recent music, Hatzis tells us, is "non-elitist." It originates in a process of deliberate "ego removal," and is "delivered in a language that everyone can understand.” In his on-line newsletter, he has described a passage of his music-theatre work Constantinople as especially "strong" in its impact. The final movement of his Sepulcher of life contains, he says "some of the most beautiful music I have ever been able to capture on paper," adding however that it represents a "stumbling block" for musical colleagues who are unable to accept its "Disneyesque" simplicity. "Ego removal” evidently does not produce uniformly superior music: some passages, some works, are "stronger" or more "beautiful" than others.

Though deploring current "commercial products," Hatzis nevertheless observes the overwhelming success of pop-music forms, and advises his fellow composers to recognize it by writing at the lowest common denominator of taste, in a language that "everyone can understand." But he follows this by proposing they should aim to raise the l.c.d. of pop, as if their duty is not only to write pop but to improve it - make it “stronger” or “more beautiful.” Glass's "crossover" music, adopting rock-like rhythms and instrumentation, enjoys great public success; but only in a limited sense has it been accepted as an escape from classical forms and formats into the world of pop. Will long works to religious texts, similarly simplified, be accepted as actual pop music? Christos Hatzis seems to think so.

I'm not convinced that music becomes spiritual or devotional by associating itself with religious topics or religious texts or by adopting some kind of lofty religious dedication. The last chorus of the St Matthew 
Passion, devoid of its text, is a sarabande - an utterly solemn ritual dance, but not essentially religious, and certainly not Christian. Musical works in many cultures, periods, and genres give off an elevated aura of solemnity that we can call "spiritual," without assigning it any more specific meaning. Such works whether by Schoenberg or Varèse, Palestrina or Bach - are serious in a true sense, in that they assume the standards of high culture. Their seriousness is integral and has nothing to do with either God or Mammon.

Is religious chanting an exception?, I hear you asking. Well, not really. It's through your experience and your education that you immediately associate the chant with religious feeling. Without a text and without the voices of Buddhists from Tibet or Benedictines from Spain, the chant melody played on a high cello (as in one of Tavener's major works) evokes religion by association, but not inherently. Composers frequently draw on associative or referential idioms, counting to some extent on the experience of their listeners. A music that "everyone can understand," (that is, whose references everyone can recognize), even in a twentyfirst-century multicultural society, may expect to encounter cultural barriers. Moreover, do we not want, and need, educated listeners? New music, for this composer, anticipates not money or power or some illusionary universal acceptance, but intelligence and imagination in its users.

If music has changed, so of course have the teaching of music, and music scholarship. John Shepherd, in the first in a recent series of essays on the future of university music studies in Canada, finds the days are "long gone" when music students immersed themselves just in music: in fact, he sees an "influx of new ideas from disciplines and intellectual trajectories not principally concerned with music” (Shepherd 2006). Thinking of my own formative years, I don't agree that a half-century ago we studied only music. Though we certainly immersed ourselves in it, we found we had to be aware of literature, history, mathematics, physics, and other such neighboring "intellectual trajectories." What do they know of music that only music know?, our mentors asked. But what Shepherd refers to is the imposition on music studies of faddish trends of thought (I'm not sure they're always "new ideas") in anthropology, sociology, semiology, communications theory, gender studies - I leave you to complete the list. It's become rare in recent years to pick up a music journal and find quotations from the music scores and transcriptions which are our primary sources. According to John Shepherd, sociologists and communications scholars outnumber music scholars in current pop-music studies. He says we're witnessing a "bridging of disciplines” (Shepherd 2006). While it's all quite stimulating, I don't see the bridge. Moreover, I wonder if we don't forfeit some musical basics in the process.

In the same collection of essays, Beverley Diamond regards the fine arts as "more central than ever" in post-secondary studies, and she expresses a hope that in future we may "produce musicians with no less knowledge and skill in one or more of the world's thousands of musical practices, but also musicians capable of understanding/engaging critical issues across genres, disciplines, cultures, and classes" (Diamond 2006). This seems to me a practical hope as things keep changing--and I love it that she retains the word musicians. 
My observations are too critical, perhaps even offensive. They are probably naïve, narrowly provincial, and, in a word, Canadian. I may regret or even deplore some of the changes I've touched on here, but I remain hooked on the musical experience, and I don't foresee the demise either of the classics I was brought up on or the "unpopular" strain to which I've been attracted in my creative work. Small companies devoted to music theatre and opera thrive in Montreal, Toronto, Vancouver, Calgary, and elsewhere. I have attended workshops of two new operas in progress, and the première of a competed new work, this year already, and I know there are more in preparation. Workshops and performances attract animated small audiences. The newmusic societies founded forty years ago (the SMCQ in Montreal, New Music Concerts and Arraymusic in Toronto) have remained active, and have generated many rival groups both in those cities and in other parts of the country. The associate-composer roster of the Canadian Music Centre and the membership lists of the various professional societies have grown enormously. I often reflect that there are too many composers and too much music - but would I rather see the opposite? No.

I find genuineness in local and personal experience; it appears to my critical sense as real and verifiable. I think I have a habit of seeing the world in a grain of sand. Most of the recent "vital signs" cited, you notice, are "small." Instead of a music that "everyone can understand," how about a music that is available to anyone who is willing to give it their attention? (and of course I don't mean just musicians). Small is beautiful: think small.
Dans les années 1960, les parents disaient concernant la musique pop qu'écoutaient leurs ados, « quoi que ce soit, ce n’est certainement pas de la musique ». Mais la musique change toujours, et il nous faut réviser nos définitions de temps en temps.

Le 9 janvier 1992, à Toronto, a eu lieu une réunion très significative. Elle marquait en effet un changement de pouvoir dans notre vie musicale et aussi dans notre répertoire. Les membres de la société des droits d'auteur, SOCAN, ont approuvé une nouvelle formule électorale pour leur comité de direction. Le résultat: les compositeurs " sérieux ", même assurés d'une voix à la table, cédaient la majorité aux compositeurs " non-sérieux », c'est-à-dire pop. On a changé les termes plus tard en ceux de compositeurs « de concert » et « populaires ». Peu après cette réunion, les nouveaux directeurs ont aboli le système précédent qui favorisait les compositeurs de concert. Par cette décision, on aller traiter les chansons populaires et les œuvres symphoniques exactement de la même façon.

C’est peut-être là qu'a commencé cette mentalité commerciale qui domine notre musique aujourd'hui. Citons par exemple le déclin de l'espace donné à la musique sérieuse dans les journaux et à la radio. Un magasin de " Musique " où nous aurions cherché autrefois des partitions, nous offre maintenant des disques pop et des instruments électroniques.

La musique souffre de plus en plus d'un traitement désinvolte. On l'entend non 
seulement « en direct », mais aussi (peut-être le plus souvent) par les moyen technologique, ce qui peut nous inviter à l'ignorer. De plus, les œuvres servent d'accompagnement à n'importe quoi, ou sont interrompues en miphrase. Ce sont les mêmes conditions pour toute la musique, soit-elle classique, contemporaine, ou populaire.

Les genres de musique populaire sont tellement nombreux! Une annonce en donne plus de quarante. Est-ce qu'il existe un grand public, un grand marché pour ces musiques? Il semble au contraire que ce public soit multiple, un agrégat de plusieurs petits publics ou petits marchés, dont celui de la musique des compositeurs "sérieux" ou "de concert." Le regretté Harry Somers, quand on lui demandait quelle sorte de musique il composait, répondait « de la musique nonpopulaire ». Mais on peut considérer que son petit coin du répertoire n'est pas sans importance rélativement aux produits variés du secteur pop. En passant en revue les nombreux termes désignant ce répertoire, on note une nouvelle suggestion : « la musique raffinée ». C'est l'historienne Elaine Keillor qui l'a proposé. Mais ce terme n'a-t-il pas un relent d'aristocratie? Les compositeurs veulent toujours éviter les accusations de snobisme.

Un mythe trop souvent accepté est le suivant : le modernisme, soit de la génération de Stravinsky ou de celle de Stockhausen, a été décidément défait par le mouvement d'accessibilité dans les dernières décennies du siècle passé. Pourtant, on n'a pas cessé de jouer les chefs-d'œuvres du répertoire moderniste.

Pour les musicologues étatsuniens Richard Taruskin et Joseph Horowitz, les traditions musicales de l'occident vont disparaître dans l'avenir immédiat. Les œuvres "méditativesminimalistes" de John Tavener et Arvo Pärt sont, dit Taruskin, les plus "vendables" (notons le terme commercial) de notre temps. Pour lui, donc, la musique occidentale va finir comme elle a commencé, dans le chant d'église. Horowitz regarde comme personnalités-clés dans la scène musicale contemporaine les exécutants plutôt que les compositeurs. On perçoit ici une tendance des discours étatsuniens maintenant à abandonner les hommages coloniaux à la culture importée des empires européens en faveur des idôles nouvelles et indigènes - Copland, Gershwin et des nouveaux styles, pluralistes, démocratiques, et indiscutablement populaires. C'est la musique d'un nouvel empire culturel.

La Passio d'Arvo Pärt, interprétée récemment par un chœur torontois, exige deux solistes, un grand chœur, une petite ensemble de huit voix, et cinq instruments. La pièce dure plus de deux heures. Elle marche constamment dans les mêmes rythmes et sur les notes de la même gamme (la mineur), sauf à la fin où surgit un « Amen » très fort sur l'accord de ré majeur. Simpliste plutôt que simple, elle n'est pas très émouvante et n'élève pas tellement.

Rappellons-nous que, "vendable" ou non, l'école Tavener-Pärt n'est pas la seule tendance de la composition actuelle. Par exemple, dans son dixième décennie, Elliott Carter continue à produire de nouvelles œuvres d'un style moderniste avancé. Sa musique, dit-il, est assez "accessible" - aux musiciens. D’autres personnes travaillent avec succès dans des jardins stylistiques bien variés - expérimentaux, conservateurs, etc. Mais, comme le demande Bruce Mather, est-ce que ces activités constituent un répertoire? C'est 
un répertoire prêt à être étudié, mais ce n’est pas souvent qu'on le joue ou l'entend.

Le compositeur Christos Hatzis a publié (en ligne) deux études provocatrices : «Musique pour l'amour de Dieu » (2004) et « Sur la religion, la politique, et la musique contemporaine »(2006). Nous pourrions y voir à la fois un manifeste sur son propre façon de composer et un attentat contre presque toutes les façons d'écrire du siècle dernier. Selon Hatzis, les positions esthétiques de ses collègues ne sont que des "jeux de langage.” Il voit dans leurs œuvres ce qu'il appelle de la pseudo-science, du nihilisme, de l'élitisme - en ne donnant aucun nom. Ce qui nous laisse conjecturer : Ravel? Berg? Feldman? Glass? Les seuls noms qu'il cite, et avec approbation, sont ceux de Tavener et Pärt. Ses propres œuvres récentes, nous dit-il, sont écrites selon un processus de « suppression de l’égo », et « dans un langage que tout le monde peut comprendre ». Il encourage ses confrères à simplifier leur partitions et à s'exprimer comme les chansonniers du monde pop. Est-ce que ces œuvres, longues et pleins de redites, sur des textes liturgiques ou méditatives, peuvent devenir du vrai pop? Hatzis semble le croire.

La musique dit "religieuse" ne tire pas d'ellemême sa saveur sacrée mais elle le fait par association avec un texte sacré ou une dédicace élevée. Le plainchant, si au lieu de le chanter on le joue dans le haut registe du violoncelle, prend une expression sérieuse, bien sûr, mais c'est notre expérience et notre éducation qui lui donnent sa signification religieuse. Les compositeurs ont souvent employé des idiomes empruntés à des genres établis, soit folkloriques ou historiques. Une musique dont les emprunts et les références culturelles serait compris par tous est difficile, sinon impossible, à imaginer dans notre société multiculturelle du nouveau millénaire. De plus, la musique ne mérite-t-elle pas un public cultivé?

Si la musique a changé, il en va de même pour l'éducation musicale. Dans une compilation de commentaires intitulée "Le futur des études musicales au Canada », John Shepherd identifie plusieurs disciplines et spécialisations qu'il est nécessaire de considerer avant d'entreprendre une carrière en musique. Pour sa part, l'ethnomusicologue Beverley Diamond espère voir « des musiciens [sic!] dont les connaissances poussées dans un domaine se conjuguent à un jugement critique face aux divers genres, disciplines, cultures, et groupements sociaux auxuels ils sont confrontés ».

En regardant ces changements d'un œil trop critique, je risque de laisser une impression de désespoir. Or, je n’observe aucune « mort de la musique ». Bien au contraire. De petites compagnies vouée au théàtre lyrique prolifèrent partout au Canada. Les plus anciens ensembles de musique nouvelle ceux créés il y a plus de quarante ans - ont aujourd'hui nombre de rivaux plus jeunes. L'été qui vient nous apportera des festivals de musique contemporaine à Saint-Jean, à Victoria, à Toronto Island, et à Victoriaville pour ne donner que quelques exemples. Les Canadiens savent apprécier l'authenticité des performances locales et la beauté des petites entreprises musicales. 


\section{References}

Beckwith, John. 1997a. “Accessibility, elitism, oblivion: options for the composer.” Unpublished paper, Canadian University Music Society, Memorial University, St John’s, 14 June.

--- $\quad$ 1997b. Music papers: articles and talks by a Canadian composer, 1961-1994. Ottawa: Golden Dog Press.

--- 2005.“The state of composition.” Women’s Musical Club of Toronto News and notes, 31 (February).

Diamond, Beverley. 2006. "There's no going back.” Ecclectica, e-magazine, Brandon University (September). <www.ecclectica.ca/issues/2006/2>

Hatzis, Christos. 2004. "Music for God’s sake.” <www.chass.utoronto.ca/ chatzis>

--- 2006. "On religion, politics, and contemporary music.” <www.chass.utoronto.ca/ chatzis>

Hitchcock, H. Wiley. 1969. Music in the United States: a historical introduction. Englewood Cliffs, NJ: Prentice-Hall.

Horowitz, Joseph. 2005. Classical music in America: a history of its rise and fall. New York: W. W. Norton \& Co.

Keillor, Elaine. 2006. Music in Canada: capturing landscape and diversity. Montreal and Kingston: McGill-Queen's University Press.

Shepherd, John. 2006. “The future of music studies in Canada.” Ecclectica, e-magazine, Brandon University (September). <www.ecclectica.ca/issues/2006/2>

Taruskin, Richard. 2005. The Oxford history of Western music, 6 vols. New York: Oxford University Press. 